\title{
DETERMINATION OF ANTIMICROBIAL ACTIVITY OF VARIOUS PLANT ESSENTIAL OILS ON VANCOMYCIN RESISTANT ENTEROCOCCI AND SOME PATHOGENIC MICROORGANISMS
}

\author{
Revza ÇELİK ${ }^{1}$ Esin KIRAY ${ }^{2 *}$, Ergin KARIPTAŞ ${ }^{3}$ \\ ${ }^{1}$ Kirșehir Ahi Evran University, Institute of Science, Department of Biology, 40100, Kirsehir, Turkey \\ ${ }^{2}$ Kirsehir Ahi Evran University, Vocational School of Health Services, Department of Medical Services and Techniques, 40100, Kirsehir, \\ Turkey \\ ${ }^{3}$ Kirsehir Ahi Evran University, Faculty of Medicine, Department of Medical Microbiology, 40100, Kirşehir, Turkey.
}

\begin{abstract}
In this study, it was aimed to determine the anti-bacterial activities of plant essential oils such as thyme, rosemary, sage, linden, black seed, bay leaf, peppermint, parsley, cinnamon and oleagen on vancomycin resistant enterococci (VRE) and pathogenic microorganisms of clinical importance. In the study, the inhibition zones of the plant extract of 10 plants prepared at $2.5 \mathrm{and} 5 \mathrm{mg} / \mathrm{ml}$ concentrations of VRE and various pathogenic microorganisms were detected by Disk Diffusion and Agar Well Diffusion Method. Following this, Minimal Inhibition Concentration (MIC) values of these extracts were determined. The activities of plant extracts on DNA and Gas Chromatography-Mass Spectrometry (GC-MS) analyzes were also performed. According to the data obtained, it was determined that the extracts of rosemary and sage plants showed high antibacterial effect against pathogenic bacteria. The rosemary extract was found to be the most effective extract on VRE strains, as well as medium-grade antibacterial effects on the VRE strains in oleaster, linden, thyme and mint extracts. It was also determined that extracts from different plants did not cause any change in the structure of DNA. In our study, it was determined that plant extracts that are especially effective on VRE strains have the potential to be used in the treatment of VRE. The results of this study should be taken into account in the research of drugs that can be used in the treatment of VRE and more in vitro and in vivo research should be carried out in this field.
\end{abstract}

Keywords: Vancomycin-resistant enterococci, Plant volatile oils, Antibacterial activity

\begin{tabular}{lll}
\hline *Corresponding author: Kirsehir Ahi Evran University, Vocational School of Health Services, Department of Medical Services and Techniques, 40100, Kirsehir, Turkey \\
$\begin{array}{lll}\text { E mail: esin.kiray@ahievran.edu.tr (E. KIRAY) } & \\
\text { Revza ÇELiK } & \text { (D) https://orcid.org/0000-0002-6733-617X } & \text { Received: September 09, 2020 } \\
\text { Esin KIRAY } & \text { (iD } h \text { https://orcid.org/0000-0002-6908-5909 } & \text { Accepted: November 06, 2020 } \\
\text { Ergin KARIPTAȘ } & \text { (D) https://orcid.org/0000-0001-6513-9589 } & \text { Published: January 2021, 2021 }\end{array}$
\end{tabular}

Cite as: Çelik R, Kıray E, Kariptaş E. 2021. Determination of Antimicrobial Activity of Various Plant Essential Oils on Vancomycin Resistant Enterococci and Some Pathogenic Microorganisms. BSJ Health Sci, 4(1): 26-34.

\section{Introduction}

Enterococci are found as natural flora bacteria in the mouth, vagina, bile ducts and urethra on the surface of the human intestine (Çaylan, 2004). In addition to having a low rate of disease ability, they can cause serious diseases (Shepard and Gilmore, 2002). While these bacterial groups, which are found intensely in the abdominal cavity, cause infectious diseases such as bacteremia and endocarditis, they may rarely cause meningitis, skin and soft tissue infections. Some members of the enterococcus species can grow in a wide temperature range $\left(10{ }^{\circ} \mathrm{C}-45{ }^{\circ} \mathrm{C}\right)$ outside the host organism, maintain their viability at different $\mathrm{pH}$ levels and even in the presence of detergents. (Lautenbach et al., 1999; Patterson, 2000; Shepard and Gilmore, 2002). It is resistant to dry conditions; therefore, Enterococci can remain in hospital settings for a long time and spread easily among patients. (Asgin, 2020). It may predominate the gut microbiota of long-term hospitalized patients, especially those who taking broad-spectrum antibiotics (Reyes 2016).
Vancomycin resistant enterococci (VRE) first appeared in the 1980s and a significant threat to patients in hospital settings today. The incidence of VRE infections has increased steadily in different regions in recent years. For this reason, VRE is currently considered by the World Health Organization as a high-level priority public health issue for the research and development of new therapeutic strategies (Correa et al., 2020).

Increased multi-drug resistance among microorganisms has made it necessary to search for new sources in order to require new antimicrobial compounds. (Akgül, 2014). In this context, determining the effective plant species against pathogenic microorganisms and the active substances contained in these species has become a field of intensive study in the world. Since essential oils have a complex structure containing different components, their biological effects are also observed. Many essential oils may show different antimicrobial effects depending on the properties of the active ingredient they contain. (Ertürk et al. 2010).

The large number of different groups of chemical 
components in essential oils explains that their antibacterial activities depend on different mechanisms. Antimicrobial substances obtained from perennial plants can alter the enzymatic reactions of microbial metabolism, inhibit the uptake of nutrients in the environment, make changes in the structure of the cell membrane, inhibit enzyme synthesis at the ribosomal and nucleus level. (Toroğlu ve ark., 2006; Evren, 2011). When the antimicrobial properties of essential oils are evaluated, it is stated that gram-negative bacteria are more resistant than gram-positive bacteria and that this resistance of gram-negative bacteria may arise from the cell wall (Evren, 2011).

In this study, it was aimed to determine the antimicrobial activities of thyme, rosemary, sage, lime, black seed, bay leaf, mint, parsley, cinnamon and oleaster plant extracts grown in Kırşehir province by various methods against VREs and some pathogenic bacteria.

\section{Materials and Methods}

\subsection{Bacterial Cultures}

In order to determine the antimicrobial activity of plant extracts in our study, Enterococcus feacalis ATCC 29212, Staphylococcus aureus ATCC 29213, Enterobacter aerogenes ATCC 13048, Pseudomonas aeruginosa ATCC 27853, Bacillus subtilis ATCC 23857, Bacillus cereus ATCC 14579, Escherichia coli ATCC 25922, Aeromonas hydrophila ATCC 7966, Shigella dysenteriae ATCC 11835, Listeria monocytogenes ATCC 19111, Proteus mirabilis ATCC 29906 were obtained from the Microbiology Laboratory of the Faculty of Arts and Sciences at Kırşehir Ahi Evran University. VRE Enterococcus faecium, VRE1, VRE2, VRE3, E. feacalis, VRE ATCC 51299 strains were obtained from Kırşehir Ahi Evran University Training and Research Hospital Microbiology Laboratory.

\subsection{Preparation of Plant Extracts}

In this research, thyme, rosemary, sage, lime, black seed, bay leaf, mint, parsley, cinnamon and oleaster plants, which are very common among the plant varieties in our country, were left to dry in the laboratory environment (at room temperature). The Soxhlet device (isolab soxhlet NS 29/32 $30 \mathrm{ml}$ ) was used to obtain plant extracts. Plants were treated with $200 \mathrm{ml}$ of solvent for 8 hours (h). In the study, ethanol and n-hexane were used as solvents. The extracts obtained were evaporated until the plant extract remained on the rotary evaporator (Heidolph Hei-Vap Advantage ML / G1). The prepared extracts were kept at $+4{ }^{\circ} \mathrm{C}$ until use. Concentrated extracts were dissolved with DMSO (dimethyl sulfoxide acid) to obtain stock solutions with a final concentration of $2.5 \mathrm{mg} / \mathrm{mland} 5 \mathrm{mg} / \mathrm{ml}$. Stock solutions were stored in the refrigerator at $-20^{\circ} \mathrm{C}$ until use (Figure 1).

\subsection{Determination of Antimicrobial Activity by Agar Well Diffusion Method}

Antimicrobial efficacy was determined by agar well diffusion method and disk diffusion method (Kalemba and Kunicka, 2003). In the antimicrobial activity test of plant essential oils, Tryptic Soy Broth (TSB) medium for pathogen test bacteria and sheep blood agar medium for VRE bacteria were used. After the at $37{ }^{\circ} \mathrm{C} 18$ hours (h) incubation, the strains were spread homogeneously to the Tryptic Soy Agar (TSA) media and sheep blood agar medium with a sterile drigalski spatula so that the final concentration was $1 \times 10^{9} \mathrm{CFU} / \mathrm{ml}$.

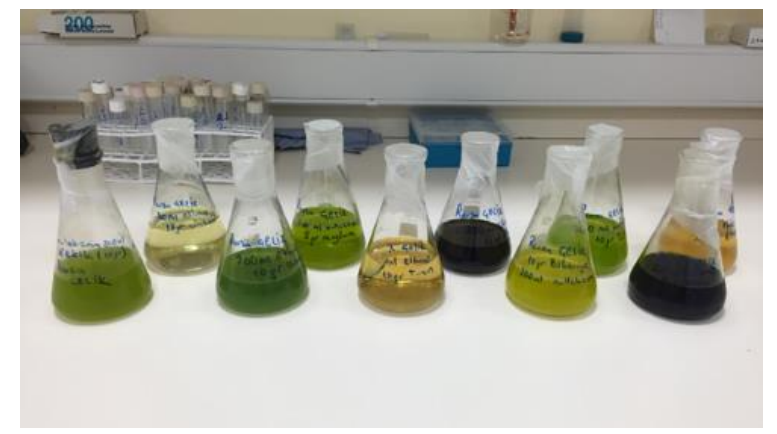

Figure 1. Plant extracts obtained from Soxhlet extraction.

After the plates were dried at room temperature for 2 hours, wells with a diameter of $6 \mathrm{~mm}$ were opened on them.

Plant extracts (rosemary, mint, oleaster, thyme, lime, black seed, parsley, sage, bay, cinnamon) obtained in the study were added to wells drilled in different concentrations (2.5 and $5 \mathrm{mg} / \mathrm{ml}$ ) and incubated at 37 ${ }^{\circ} \mathrm{C}$ for 24 hours. Inhibition zone diameters of essential oils were measured in $\mathrm{mm}$ after incubation. Essential oil with a diameter of $12.0 \mathrm{~mm}$ and narrower does not have enough antibacterial effect on the existing bacteria $(-)$, diameters at 12 and $21 \mathrm{~mm}$ limbs are moderately active $(+)$, diameters from $21 \mathrm{~mm}$ to $30 \mathrm{~mm}$ are active (++) On the other hand, diameters of $30 \mathrm{~mm}$ and above are considered to be very active (+++) (Djabou et al., 2013). Our study was carried out in duplicate for each microorganism and plant extracts.

\subsection{Determination of Antimicrobial Activity by Disc Diffusion Method}

In this method; pathogenic test bacteria activated overnight in TSB liquid medium spread to TSA solid medium (Sandri et al. 2007). Discs impregnated with plant extracts in concentrations of $5 \mathrm{mg} / \mathrm{ml}$, previously prepared $(6 \mathrm{~mm})$ were placed in petri dishes containing pathogenic bacteria. The petri plates were left in 24-hour incubation at $37{ }^{\circ} \mathrm{C}$. The zone diameters formed around the discs in the petri dishes after incubation were measured in mm.

\subsection{Minimal Inhibition Concentration (MIC) Value Determination}

Nutrient Broth (NB) broth was used for the production of bacteria and determination of antibiotic MIC values. Pathogenic test bacteria were activated in a $5 \mathrm{ml} \mathrm{NB}$ liquid medium at $37{ }^{\circ} \mathrm{C}$ for $18 \mathrm{~h}$ in a $175 \mathrm{rpm}$ shaking incubator. Activated bacterial cells were added in $50 \mathrm{ml}$ NB medium, approximately $10^{6}$ cells per $1 \mathrm{ml}$, in accordance with 0.5 McFarland turbidity standards. NB medium containing microorganisms and plant extracts of 
different concentrations were mixed in an equal volume and then serial dilutions were made. Tubes were incubated at $37{ }^{\circ} \mathrm{C}$ for $24 \mathrm{~h}$. The last tube without bacterial growth was determined as MIC value. MIC values obtained in the study were indicated as $\mu \mathrm{g} / \mathrm{ml}$.

\subsection{Detection of DNA Cleavage Activity in Plant} Extracts

Detection of DNA cleavage activity in plant extracts was evaluated in Amasya University Faculty of Education Microbiology Laboratory. Extracts obtained were performed using pBR322 DNA cleavage using agarose gel electrophoresis. Extracts were prepared by dissolving in DMSO at a concentration of $2 \mathrm{mg} / \mathrm{ml}$. The pBR322 plasmid DNA (0.25 ug / $\mathrm{mL}$ ) was treated with each extract and the mixture was incubated at $37^{\circ} \mathrm{C}$ for $4 \mathrm{~h}$. The pBR322 plasmid DNA treated only with water $\left(\mathrm{H}_{2} \mathrm{O}\right.$ control) and $1 \mu \mathrm{l}$ DMSO (DMSO control) was used as the DNA control. After the prepared incubation samples were loaded on $1 \%$ agarose gel, the electrophoresis was carried out at $120 \mathrm{~V}$ in 80 minutes TAE buffer $(40 \mathrm{mM}$ Tris / acetate and $1 \mathrm{mM}$ EDTA, pH 8.0) and the obtained gels in EtBr (Ethidium Bromide) (1 $\mathrm{mg} / \mathrm{mL}$ ) was examined in the UV illuminator after staining (Figure 2).

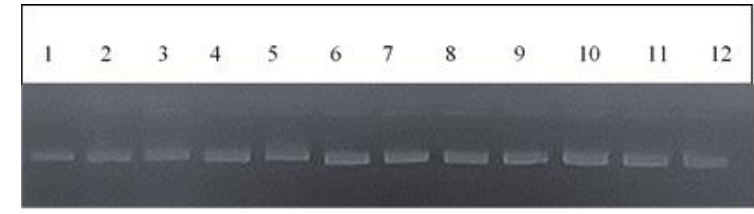

Figure 2. Effect of plant extracts on DNA structure. 1= pBr322 DNA control $\mathrm{H}_{2} \mathrm{O}, 2=$ pBR322 control DMSO, $3=$ Oleaster, $4=$ Cinnamon, $5=$ Nigella, $6=$ Thyme, $7=$ Sage, $8=$ Mint, 9= Linden, 10= Rosemary, 11= Bay leaf, 12= Parsley.

\subsection{Gas Chromatography-Mass Spectrometry (GC-} MS) Analysis

The analysis of the essential oils obtained in this study was carried out using the Gas Chromatography Mass Spectrometer (GC / MS) system available at the Aksaray University Scientific and Technological Application and Research Center. Some of the extracts of sage, rosemary, thyme, peppermint and cinnamon plants were diluted in methanol, and thyme oil from industrially produced oils of the same plants was diluted in methanol and other oils were diluted in hexane and qualitative analysis of samples were performed.

\section{Results}

\subsection{Antimicrobial Activity of Plant Essential Oils}

It is about disc diffusion method, in which 10 different essential oils (thyme, mint, bay leaf, parsley, oleaster, ilamlam, rosemary, sage, black seed and cinnamon) have different effects $(2.5 \mathrm{mg} / \mathrm{ml}$ and $5 \mathrm{mg} / \mathrm{ml})$ for pathogenic microorganisms. Inhibition zone diameters obtained by agar well diffusion method are shown in Table 1, and zone diameters obtained by disc diffusion method are shown in Table 2. As seen in Table 1, all of the plant essential oils obtained in the study showed a high antimicrobial effect on various pathogenic microorganisms. However, as can be seen in Table 2, this effectiveness could not be determined exactly by the disk diffusion method. In this antimicrobial study, the zone diameters obtained in two different concentrations that we used as $2.5 \mathrm{mg} / \mathrm{mland} 5 \mathrm{mg} / \mathrm{mlin}$ agar well diffusion method increased proportionally with the concentration ratio (Table 3).

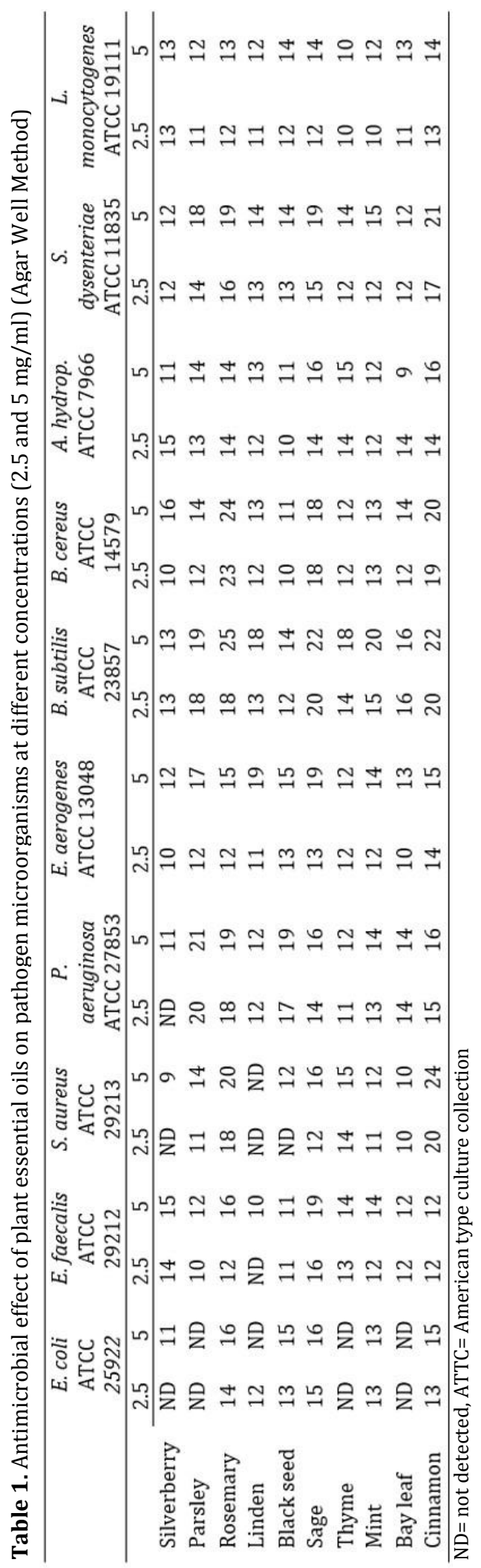




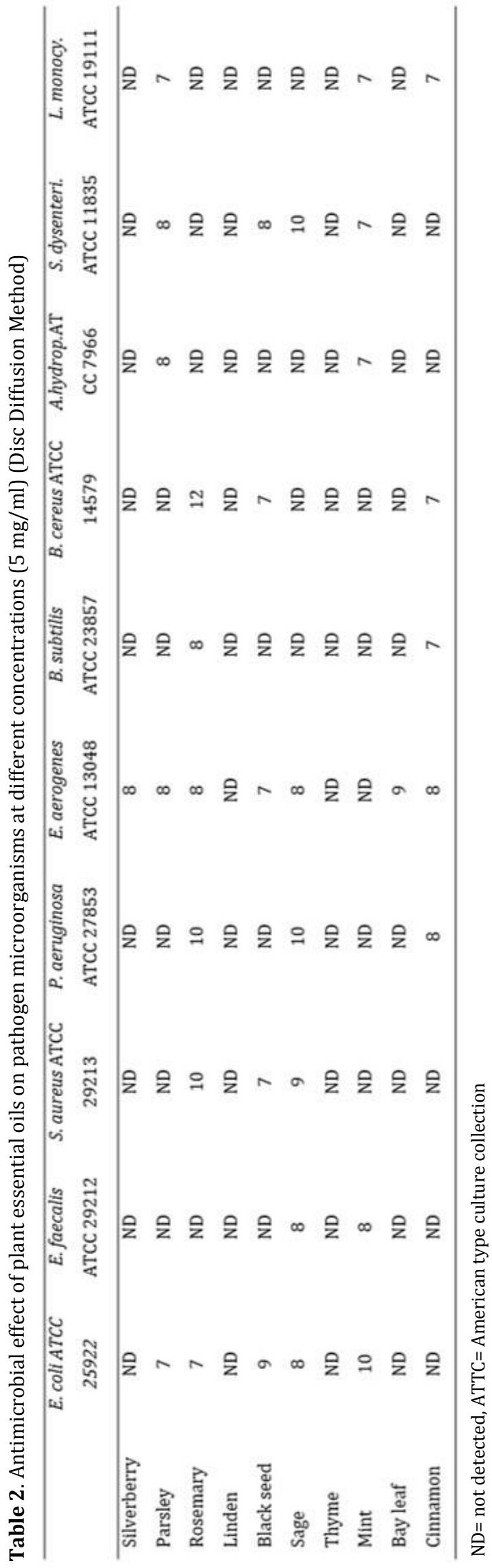

In our study, VRE 1 concentration of oleaster, rosemary, sage, thyme, peppermint, bay leaf and cinnamon essential oils showed a moderate antibacterial effect. The oleaster essential oil showed higher antibacterial activity against
VRE 1, rosemary and lime essential oil VRE 2 compared to other oils and formed the widest inhibition zone. While rosemary and lime essential oils prepared as 5 $\mathrm{mg} / \mathrm{ml}$ in our study showed a very high effect on the development of VRE 2; Thyme, peppermint, cinnamon, oleaster, cinnamon showed low effects, while parsley, linden and bay leaf also had a moderate antibacterial effect. However, none of the essential oils impregnated with sterile discs showed any antibacterial effect against VRE 2 and did not form an inhibition zone.

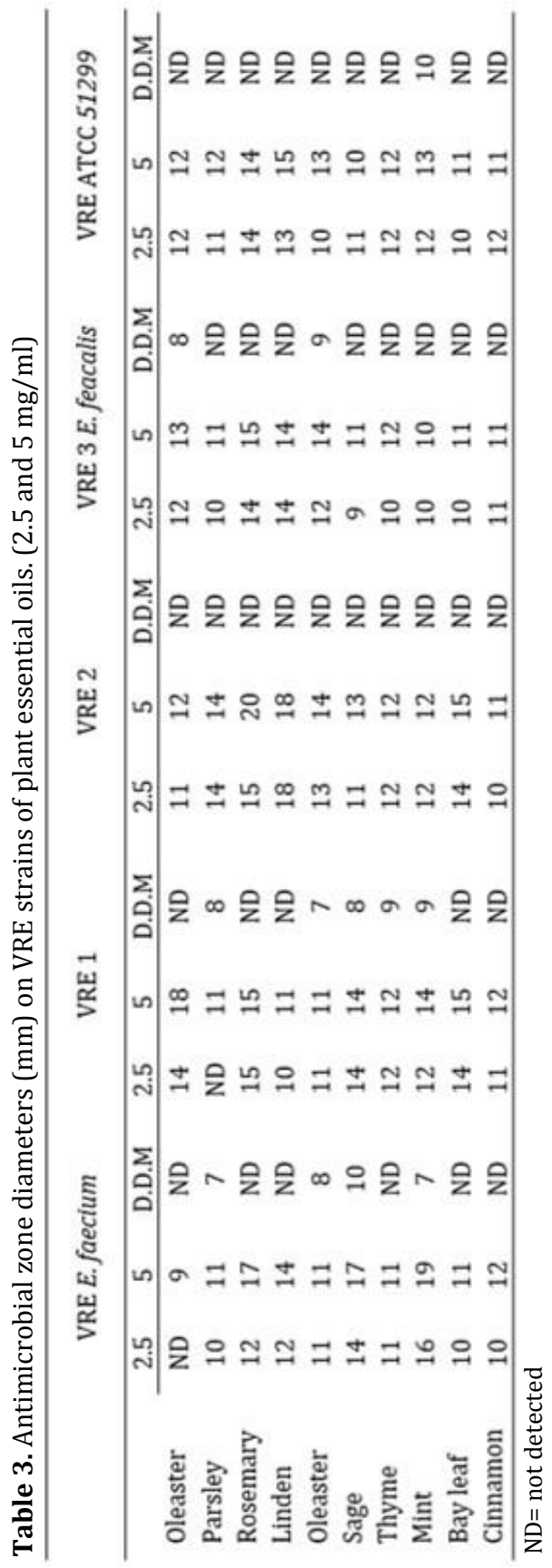

In our study, the concentrate prepared as $5 \mathrm{mg} / \mathrm{ml}$ had a moderate antibacterial effect on the VRE 3 E. feacalis of essential oil, lime, black seed and thyme essential oils. The rosemary essential oil VRE 3 E. feacalis showed higher antibacterial activity against VRE 3 E. feacalis than other oils and formed the widest inhibition zone. On the 
other hand, essential oils that are impregnated with sterile discs, except for oleaster and black seed essential oils, do not show any antibacterial effect; although these essential oils did not have sufficient effect, they formed an inhibition zone. In our study, the essential oils of cinnamon, bay leaf and sage did not show sufficient effect on VRE ATCC 51299, while lime and rosemary essential oils showed high antimicrobial effects.

\subsection{DNA Cleavage activity of plant essential oils}

In this study, it was investigated whether the extracts obtained from different plants cause any change in the structure of DNA. As can be seen in Figure 1, samples 1 and 2 were used as controls. As a result of the study, the effects of the extracts obtained from plants on DNA were examined and it was determined that no plant extract caused any deterioration in the DNA structure of the plant, so it had no effect on the plasmid DNA.

\subsection{Minimal Inhibition Concentration (MIC) Values}

The MIC of plant extracts obtained in this study on various pathogenic microorganisms was determined. Stock solutions of the plant extracts used were prepared and used in DMSO. MIC values of plant extracts against pathogenic microorganisms are shown in Table 4.

Table 4. MIC values of plant extracts $(\mathrm{ug} / \mathrm{ml})$ against pathogenic microorganisms

\begin{tabular}{|c|c|c|c|c|c|c|c|c|c|c|}
\hline & 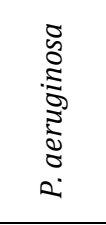 & 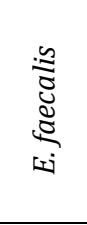 & 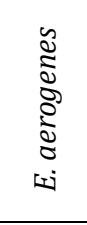 & $\begin{array}{l}\frac{0}{\mathfrak{d}} \\
\frac{2}{2} \\
\frac{1}{0} \\
\frac{2}{2} \\
\dot{\pi}\end{array}$ & 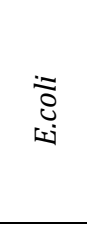 & 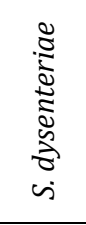 & 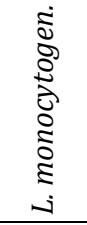 & 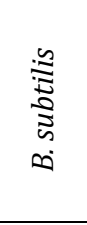 & 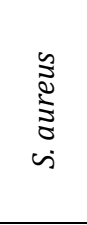 & 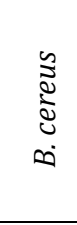 \\
\hline Bay leaf & 1875 & 937 & 3750 & 3750 & 3750 & 3750 & 3750 & 937 & 1875 & 937 \\
\hline Thyme & 234 & 58.5 & 234 & 468 & 234 & 468 & 234 & 234 & 117 & 58.5 \\
\hline Black seed & 1875 & 468 & 3750 & 1875 & 1875 & 3750 & 3750 & 1875 & 937 & 58.5 \\
\hline Linden & 1875 & 937 & 1875 & 1875 & 937 & 3750 & 3750 & 3750 & 3750 & 3750 \\
\hline Parsley & 937 & 468 & 1875 & 937 & 1875 & 3750 & 3750 & 4000 & 4000 & 4000 \\
\hline Oleaster & 937 & 1875 & 1875 & 1875 & 937 & 3750 & 1875 & 468 & 1875 & 1875 \\
\hline Rosemary & 3750 & 1875 & 1875 & 3750 & 468 & 1875 & 4000 & 4000 & 7500 & 3750 \\
\hline Cinnamon & 1875 & 937 & 1875 & 1875 & 3750 & 937 & 1875 & 468 & 937 & 468 \\
\hline Mint & 1875 & 3750 & 3750 & 3750 & 3750 & 3750 & 3750 & 3750 & 3750 & 1875 \\
\hline Sage & 3750 & 937 & 3750 & 3750 & 3750 & 3750 & 3750 & 3750 & 3750 & 3750 \\
\hline DMSO & $>5000$ & & & & & & & & & \\
\hline
\end{tabular}

In this study, it was determined that the MIC values in the control samples were $>5000 \mu \mathrm{g} / \mathrm{ml}$. In addition, when the MIC values of the extracts were analyzed, it was observed that this value varied between 58.5-4000 $\mu \mathrm{g} / \mathrm{ml}$. As can be seen from here, it is seen that some plant extracts have high antimicrobial effect on the life of bacteria.

As seen in Table 4, the extract from the bay leaf was found to have a moderate effect on E. faecalis, B. subtilis and B. cereus $(937 \mu \mathrm{g} / \mathrm{ml})$. Thyme extract appears to have a high antimicrobial effect on all microorganisms. It is seen that the plant extract obtained from Nigella is effective only on E. faecalis and B. cereus (MIC values are $468 \mu \mathrm{g} / \mathrm{ml}$ for E. faecalis, $58.5 \mu \mathrm{g} / \mathrm{ml}$ for B. cereus). Parsley only on E. faecalis $(468 \mu \mathrm{g} / \mathrm{ml})$, Spindle only on $B$. subtilis $(468 \mu \mathrm{g} / \mathrm{ml})$, Rosemary only on E. coli $(468$ $\mu \mathrm{g} / \mathrm{ml}$ ), and Cinnamon on B. subtilis and B. cereus (468 $\mu \mathrm{g} / \mathrm{ml}$ ) has been found to have significant effects.

\subsection{Gas Chromatography-Mass Spectroscopy (GC-MS)} Analysis

In this study, GC-MS analysis of these extracts was performed by selecting 5 plant extracts (sage, rosemary, mint, thyme and cinnamon) that showed the most antimicrobial effects from 10 different plant extracts. As a result of GC-MS analysis of sage herbal extract shown in Table 5, four different components were determined and porphin $(4.93 \%)$ was the most common chemical in the composition.
Table 5. GC-MS analysis results of sage herbal extract.

\begin{tabular}{|c|c|c|}
\hline Name & non name & $\begin{array}{l}\text { Composition } \\
\text { rate } \%\end{array}$ \\
\hline \multicolumn{3}{|l|}{ Sage } \\
\hline \multirow{4}{*}{$\begin{array}{l}9.12- \\
\text { Octadecadienoic acid } \\
\text { (9e.12e)-9.12- } \\
\text { octadecadienoic acid }\end{array}$} & DMSO & 94.21 \\
\hline & Linoleic acid & 0.27 \\
\hline & $\begin{array}{c}\text { cis-Linoleic } \\
\text { acid }\end{array}$ & 0.59 \\
\hline & Porphin & 4.93 \\
\hline
\end{tabular}

As a result of GC-MS analysis of rosemary herb extract shown in Table 6, seven components were found and the most common chemical substances in their composition were cis-Linoleic acid (0.27\%) Eucalyptol (Ökaliptaol) $(0.18 \%)$. The only chemical substance in the composition of thyme herbal extract shown in Table 7 as a result of GC-MS analysis is o-Cymen-5-ol Thymol (1.14\%). Porphin (4.96\%) is the most common chemical substance among the four components encountered as a result of GC-MS analysis of peppermint herb extract shown in Table 8. As a result of GC-MS analysis of cinnamon plant extract shown in Table 9, six components were found. Its main components are specified as Cinnamaldehyde (2.75\%) and Cinnamaldehyde Dimethyl Acetal (1.21\%). 
Table 6. Results of GC-MS analysis of rosemary herb extract

\begin{tabular}{lcc}
\hline Name & $\begin{array}{c}\text { Common } \\
\text { name }\end{array}$ & $\begin{array}{c}\text { Compositi } \\
\text { on rate\% }\end{array}$ \\
\hline Rosemary & DMSO & 99.30 \\
\hline $\begin{array}{l}\text { 1.3.3-Trimethyl-2- } \\
\text { oxabicyclo[2.2.2]octane }\end{array}$ & $\begin{array}{c}\text { Eucalyptol } \\
\text { (Ökaliptaol) }\end{array}$ & 0.18 \\
$\begin{array}{l}\text { Bicyclo[2.2.1]heptan-2- } \\
\text { one, 1.7.7-trimethyl }\end{array}$ & $\begin{array}{c}\text { Camphor } \\
\text { (Kafur) }\end{array}$ & 0.05 \\
$\begin{array}{l}\text { trimethylbicyclo[2.2.1]h } \\
\text { eptane }\end{array}$ & Borneol & 0.04 \\
$\begin{array}{l}\text { 2-(4-Methyl-3- } \\
\text { cyclohexen-1-yl)-2- } \\
\text { propanol }\end{array}$ & Alpha- & 0.04 \\
$\begin{array}{l}\text { 9.12-Octadecadienoic } \\
\text { acid }\end{array}$ & Linoleic acid \\
$\begin{array}{l}\text { 9e.12e)-9.12- } \\
\text { octadecadienoic acid }\end{array}$ & Cis-linoleic & 0.13 \\
\hline
\end{tabular}

Table 7. Results of GC-MS analysis of thyme herb extract

\begin{tabular}{lcc}
\hline Name & Common name & $\begin{array}{c}\text { Composition } \\
\text { rate\% }\end{array}$ \\
\hline Thyme & DMSO & 98.86 \\
\hline & o-Cymen-5- & 1.14 \\
3-Methyl-4- & olThymol & \\
isopropylphenol &
\end{tabular}

Table 8. GC-MS analysis results of peppermint plant extract.

\begin{tabular}{lcc}
\hline Name & Common name & $\begin{array}{c}\text { Compositio } \\
\text { n rate\% }\end{array}$ \\
\hline Mint & DMSO & 94.37 \\
\hline $\begin{array}{l}\text { (E)-3- } \\
\text { phenylprop-2- } \\
\text { enal }\end{array}$ & Cinnamaldehyde & 0.17 \\
$\begin{array}{l}\text { 9.12- } \\
\text { Octadecadienoic }\end{array}$ & Linoleic acid & 0.31 \\
acid & & \\
& Porphin & 4.96 \\
\hline
\end{tabular}

\section{Discussion}

The most notable feature of enterococci is that they are resistant to many antimicrobial agents used in the treatment of gram-positive bacterial infections. Multiple antibiotic resistance in enterococci in Turkey as well as the whole world emerges as an important problem. In other words, the antibiotic alternatives that can be used in the treatment of enterococcal infections are quite limited (Berzeg, 2005; Karagöz, 2005). In our study, the antimicrobial activites of various plant essential oils on
VREs and various pathogenic microorganisms isolated from patients by Kırşehir Ahi Evran University Training and Research Hospital Microbiology Laboratory was investigated.

Table 9. GC-MS analysis results of cinnamon extract

\begin{tabular}{lcc}
\hline Name & Common name & $\begin{array}{c}\text { Composition } \\
\text { rate\% }\end{array}$ \\
\hline Cinnamon & DMSO & 95.58 \\
(E)-3-phenylprop- & Cinnamaldehyd & 2.75 \\
2-enal & e & \\
[(E)-3.3- & cinnamaldehyd & 1.21 \\
dimethoxyprop-1- & e dimethyl & \\
enyl]benzene & acetal & \\
[(E)-3- & Cinnamyl Aceta & 0.14 \\
phenylprop-2- & te & \\
enyl] acetate & \\
9.12- & Linoleic acid & 0.1 \\
Octadecadienoic & \\
acid & \\
(9e.12e)-9.12- & cis-Linoleic acid & \\
octadecadienoic & & \\
acid & & \\
\hline
\end{tabular}

Turkey is rich in plant ingredients and potential, there are a large number of plant species used medicinally. Researches conducted both abroad and in Turkey found that many of these plants have antimicrobial effects. In this study, extracts of 10 plants (peppermint, thyme, rosemary, lime, cinnamon, oleaster, bay leaf, black seed, parsley and sage) grown in our country and which we can easily find on the market are used.

In this study, it was observed that the plant-specific extracts studied had antimicrobial activity against VREs. The most susceptible bacterial strain to extracts is VRE 2 . It is possible to use the plant extracts that we use in our study as antimicrobial agents of modern drugs produced for the treatment of infectious diseases. It is seen that the spindle essential oil showed higher antibacterial activity against VRE 1 and the rosemary and lime essential oil showed higher antibacterial activity against VRE 2 compared to other oils.

While the rosemary and lime essential oils prepared as 5 $\mathrm{mg} / \mathrm{ml}$ in the study showed had a very high effect on the development of VRE 2; thyme, peppermint, cinnamon, oleaster, cinnamon showed low effects. In addition to these, parsley, linden and bay leaf have a moderate antibacterial effect. The rosemary essential oil, which was prepared as $5 \mathrm{mg} / \mathrm{ml}$, showed higher antibacterial activity against VRE 3 E. feacalis compared to other oils and formed the widest inhibition zone. The rosemary essential oils at the concentration of $5 \mathrm{mg} / \mathrm{ml}$ showed a 
high antimicrobial effect on VRE ATCC 51299. As a result, rosemary essential oils have been identified as the most effective vegetable oil on VRE bacteria. Samy, 2011 investigated the antimicrobial activity of 11 different essential oils on E. coli 0157:H7 and VRE and he determined that the most powerful antimicrobial activity of thyme oil was the result of the study. In our study, it was found that thyme oil is effective on various pathogens and VRE. However, in our study, it was seen that especially rosemary oil was more effective. Studies on plant essential oils have found a limited number of plants with antimicrobial activity on VRE microorganisms. One of them is Lavender essential oil. It has also been found that it has antimicrobial activity on (VRE) species (Roller et al., 2009).

It is concluded that the antibacterial activity does not depend on a single mechanism and that there are many targets in the cell, considering the excess of different groups of chemical compounds in essential oils (Toroglu et al., 2006). The antimicrobial effect of essential oils can be seen in the cytoplasm membrane with changes in structure and function. Antimicrobial substances obtained from higher plants can stop the enzymatic reactions of microbial metabolism, prevent the intake of nutrients in the environment, change the structure of the membrane, and prevent enzyme synthesis at the core and ribosomal level (Uçan, 2008). According to GM-MS analysis in our study, some plant extracts had a great effect on the life of bacteria. In particular, thyme herb extract appears to have a significant antimicrobial effect on all microorganisms. The antimicrobial properties of plant essential oils come from phenolic (thymol, kavrachrol, eugenol, etc.) and terpenoid components in their structure, and plants rich in these components are also used for therapeutic purposes. The important thing here is to obtain these components without creating any damage and use them in appropriate doses and combinations (Faydaoğlu and Rideroğlu, 2013).

In various studies on thyme oil, it has been determined that it shows high bacteriostatic activity on both Grampositive and Gram-negative bacteria (Winska, 2019). In a study investigating the in vitro antimicrobial activity of Thymus vulgaris essential oil against oral pathogens, its effectiveness on p-hemolytic Streptococci ssp. strains (Fani and Kohanteb, 2017), Salehi et al. determined that oregano oil inhibited S. aureus ATCC 25923 and K. pneumoniae ATCC 13882 strains (Salehi, 2019). In many reviews, it has been stated that the antimicrobial activity of T. vulgaris is due to its high thymol and carvacrol content, which can form hydrogen bonds with the active site of many enzymes (Marchese, 2016).

In general, the antimicrobial properties of vegetable essential oils come from phenolic (thymol, kavrachrol, eugenol, etc.) and terpenoid components, and plants rich in these components are also used for treatment. The important thing here is to obtain these components without causing any damage and to use them in appropriate doses and combinations (Benefitoğlu and
Rideroğlu, 2013).

It is thought that sage, cumin, rosemary oils and their main components are ineffective or less effective against Gram (-) bacteria, the reason of which is the external membranes of Gram (+) bacteria, which are also composed of lipopolysaccharide and protein in Gram (-) bacteria. The lipopolysaccharide structure limits the diffusion of hydrophobic compounds (Burt, 2004; Delamare et al., 2007). According to some research results, Burt 2004 stated that there is no difference between Gram (-) and Gram (+) bacteria, and according to some studies, the responses of Gram (-) and Gram (+) bacteria may differ. According to these results, the important factor in antimicrobial activity is not only the properties of the target microorganism, but also the chemical composition of the essential oil is different (Ouattara et al., 1997; Sağdıç and 2003).

In our study, it was seen that peppermint essential oil, which has a strong antimicrobial effect especially on VRE E. faecium, has a small effect on other pathogenic microorganisms. In other studies, it has been pointed out that although peppermint essential oil alone has a weak antibacterial activity, it may have a synergistic effect with other essential oils or substances. One of the popular preparations used to treat headaches, colds, cough, mild spinal gastrointestinal complaints and relieve local muscle pain is Olbas $\AA$ Tropfen (Olbas). It contains essential oils such as peppermint essential oil (5.3 g), eucalyptus (2.1 g), cajuput and to a lesser extent juniper essential oil (0.3 g). Antibacterial activity has been demonstrated against many strains, including Olbas $\AA$, methylcine-resistant $S$. aureus (MRSA) and VRE (Hamoud, 2012).

In our study, it was stated that cinnamon essential oil, which is weakly effective on VRE strains but has a strong antimicrobial effect on $S$. aureus ATCC 29213, P. aeruginosa ATCC 27853, B. subtilis ATCC 23857 and B. cereus ATCC 14579 strains, has also shown a strong antimicrobial effect in other studies. In particular, they showed that cinnamon essential oil has a better effect compared to essential oils such as clove, lemongrass, tea tree, ginger, basil and has very good activity against $S$. aureus, E. coli, A. baumannii and P. aeruginosa. (Chouhan, 2017). These results are similar to our study.

Various plant essential oils have been reported to show high antiproliferative effects on pathogenic microorganisms. In one study, eucalyptus, juniper, peppermint, rosemary, sage, clove and thyme oils were found to be the most effective essential oils against VRE and E. coli 0157: H7 strains with multi drug resistance. (Selim, 2011). These data are similar to the results in our study. Also, in our study, it was investigated whether the extracts obtained from different plants cause any change in the structure of DNA. As a result of the study, it has been determined that the extracts obtained from plants do not cause any deterioration in the DNA structure, therefore they have no effect on plasmid DNA. 


\section{Conclusion}

It is a known fact that bacterial resistance to antibiotics and widespread hospital infections pose a great danger to public health and our future. Therefore, it is so important to research and develop new classes of antimicrobials that are effective on pathogenic microorganisms today. For this reason, it should be aimed to know the antimicrobial properties of plants that exist in nature and to obtain plant extracts suitable for this purpose. Considering all microorganisms and plant extracts, it is seen that not all plant extracts have an antimicrobial effect and are not effective on all strains of strains with antimicrobial effect. For this reason, further research should focus on microorganisms affected by plant extracts. In the studies conducted, it can be said that especially rosemary, sage, thyme and cinnamon have high antimicrobial effects. It has been proved in national and international studies that the plants used in this study have many biological activities. In this study, this efficacy has been demonstrated and some plant extracts have also been found to be effective on VRE strains. When all the data obtained are evaluated, it can be seen that these plants can be used for different purposes in the fields of pharmacy and medicine and therefore it is worth to study more.

\section{Author Contributions}

EK, RÇ and EK; concept, EK; design, supervision, data collection and/or processing, EK, RÇ and EK; materials, $\mathrm{RC}, \mathrm{EK}$ and EK; data analysis and/or interpretation, EK and RÇ; literature search and writing.

\section{Conflict of Interest}

The authors declare that there is no conflict of interest.

\section{Acknowledgements}

This research was supported by Kirsehir Ahi Evran University Scientific Research Projects TIP.A4.07005.

\section{References}

Akgül Y. 2014. İdrar yolu enfeksiyonlarına neden olan pseudomonas aeruginosa ve klebsiella pneumoniae izolatlarına karşı bazı bitki ekstraktlarının antibakteriyel aktiviteleri. Yüksek Lisans Tezi, Nevşehir Hacı Bektaş Veli Üniversitesi Fen Bilimleri Enstitüsü, Nevşehir, pp. 57-58.

Asgin N, Otlu B. 2020. Antibiotic resistance and molecular epidemiology of vancomycin-resistant enterococci in a tertiary care hospital in Turkey. Infect Drug Resist, 13:191198.

Berzeg D. 2005. Çeşitli klinik materyallerden izole edilen enterokok suşlarında antibiyotik direnci, yüksek düzey aminoglikozid direnci ve E test ile vankomisin mik değerlerinin değerlendirilmesi. İstanbul: Haseki Eğitim ve Araştırma Hastanesi İnfeksiyon Hastalıkları ve Klinik Mikrobiyoloji Kliniği.

Burt S. 2004. Essential oils: their antibacterial properties and potential applications in foods-a review. Inter J Food Microbiol, 94: 223-253.

Correa-Martinez CL, Tönnies H, Froböse NJ, Mellmann A, Kampmeier S. 2020. Transmission of vancomycin-resistant enterococci in the hospital setting: uncovering the patientenvironment interplay. Microorganisms. 31: 8(2), 203.

Çaylan R, Üstünakın M, Kadimov V, Aydın K, Köksal İ. 2004 Fekal ve klinik örneklerden izole edilen enterokok suşlarının antibiyotiklere duyarlılıkları. Türk Mikrobiyol Cemiyeti Derg, 34: 24-28.

Delamare APL, Moschen-Pistorello IT, Artico L, Atti-Serafini L, Echeverrigaray S. 2007. Antibacterial activity of the essential oils Salvia officinalis L. and Salvia triloba L. cultivated in South Brazil. Food Chem, 100: 603-608.

Djabou N, Lorenzi V, Guinoiseau E. 2013. Phytochemical composition of Corsican Teucrium essential oils and antibacterial activity against foodborne or toxi-infectious pathogens. Food Control, 354-363.

Ertürk R, Çelik C, Kaygusuz R, Aydın H. 2010. Ticari olarak satılan kekik ve nane uçucu yağlarının antimikrobiyal aktiviteleri. Cumhuriyet Tip Dergisi, 32: 281-286.

Evren M. 2011. Uçucu Yağların antimikrobiyel özellikleri. Elektronik Mikrobiyol Derg, 09(3): 28-40.

Fani M, Kohanteb J. 2017. In vitro antimicrobial activity of Thymus vulgaris essential oil against major oral pathogens. J. Evid. Based Complem Altern Med, 22(4):660-666.

Faydaoğlu E, Sürücüoğlu MS. 2013. Tıbbi ve aromatik bitkilerin antimikrobiyal, antioksidan aktiviteleri ve kullanım olanakları. Ankara Üniversitesi Sağlı Bilimleri Fakültesi Beslenme ve Diyetetik Bölümü, Fen Bilimleri Enstitüsü Dergisi, 6(2), 233-265.

Hamoud R, Sporer F, Reichling Wink M. 2012. Antimicrobial activity of a traditionally used complex essential oil distillate (Olbas ${ }^{\circledR}$ Tropfen) in comparison to its individual essential oil ingredients. Phytomedicine, 19: 969-976.

Kalemba D, Kunicka A. 2003. Antibacterial and antifungal properties of essential oils. Current medicinal chemistry,10, 813-829.

Karagöz GD. 2005. Dr. Lütfi kırdar kartal eğitim ve araștırma hastanesi infeksiyon hastalıkları ve klinik mikrobiyoloji kliniği yoğun bakım ünitesinde vankomisin dirençli enterokok taşıyıcilığının araştııılması. pp. 5-65.

Lautenbach E, Bilker W, Brennan P. 1999. Enterococcal bacteremia: Risk factors for vancomycin resistance and predictors of mortality. Infect Control Hospital Epid, 20: 318.

Marchese A, Orhan IE, Daglia M, Barbieri R, Di Lorenzo A, Nabavi SF, Gortzi O, Izadi M, Nabavi SM. 2016. Antibacteria and antifungal activities of thymol: A brief review of the literature. Food Chem, 210: 402-414.

Ouattara B, Simard RE, Holley RA, Piette GJP, Bégin A. 1997. Antimicrobial activity of selected fatty acids and essential oils against six meat spoilage organisms. Inter J Food Microbiol, 37: 155-162.

Patterson J. 2000. New Gram-positive agents in nosocomial infection. Current Opinion in Infectious Diseases, 13: 593.

Reyes K, Bardossy AC, Zervos M. 2016. Vankomisine dirençli enterokoklar: epidemiyoloji, enfeksiyon önleme ve kontrol. Infect Dis Clin Kuzey Am, 30(4): 953-965.

Roller S, Ernest N, Buckle J. 2009. The antimicrobial activity of high-necrodane and other lavender oils on methicillinsensitive and -resistant Staphylococcus aureus (MSSA and MRSA). J Altern Complement Med, 15: 275-279.

Sağdıç O, Özcan M. 2003. Antibacterial activity of Turkish spice hydrosols. Food Control, 14: 141-143.

Salehi B, Abu-Darwish MS, Tarawneh AH, et al. 2019. Thymus spp. plants - Food applications and phytopharmacy properties. Trends Food Sci Technol, 85: 286-306.

Selen İşbilir Ş. 2008. Yaprakları salata-baharat olarak tüketilen bazı bitkilerin antioksidan aktivitelerinin incelenmesi. 


\section{Black Sea Journal of Health Science}

Doktora Tezi, Trakya Üniversitesi, Fen Bilimleri Enstitüsü, Edirne, pp. 91-104.

Selim S. 2011. Antimicrobial activity of essential oils against vancomycin-resistant enterococci (vre) and Escherichia coli o157:h7 in feta soft cheese and minced beef meat. Braz J Microbiol, 42(1): 187-96.

Sharma SK, Guleria S. 2017. Antimicrobial activity of some essential oils-present status and future perspectives. Medicines, 4: 58.

Shepard BD, Gilmore MS. 2002. Antibiotic resi,stant enterococci: the mechanisms and Dynamics of drug introduction and resistance. Microbes Infection, 4(2): 215-24
Toroğlu S, Dıgrak M, Çenet M. 2006. Baharat olarak tüketilen Laurus nobilis Linn ve Zingiber officinale Roscoe bitki uçucu yaglarının antimikrobiyel aktiviteleri ve antibiyotiklere invitro etkilerinin belirlenmesi, KSÜ Fen ve Mühendislik Derg 9(1), 20.

Uçan F. 2008. DL-Limonenin mayalar üzerine antifungal etkisi. Yüksek lisans tezi, Çukurova Üniversitesi, Fen Bilimleri Enstitüsü, Adana, pp 62.

Wińska K, Mączka W, Łyczko J, Grabarczyk M, Czubaszek A, Szumny A. 2019. Essential oils as antimicrobial agents-myth or real alternative? Molecules, 24(11): 2130. 